\title{
A Synoptic Review of Forestry and Forest Products Trade and Production in Africa- The Case of Wood and Non-Wood Forest Products in West Africa
}

\author{
John Adekunle Adesina 1,*, Jiangang Zhu ${ }^{2}$ and Tang Xiaolan ${ }^{3}$ \\ 1 College of Landscape Architecture, Nanjing Forestry University, Nanjing, 210037, China; \\ adesinajohnlloyd@gmail.com \\ 2 College of Furnishings and Industrial Design, Nanjing Forestry University, Nanjing, 210037, China. \\ austin_zhu@njfu.edu.cn \\ 3 NFU Academy of Chinese Ecological Progress and Forestry Studies, Nanjing, 210037, China; \\ xiaolant@njfu.edu.cn \\ * Correspondence: adesinajohnlloyd@gmail.com¹, austin_zhu@njfu.edu.cn² and xiaolant@njfu.edu.cn ${ }^{1,3}$
}

\begin{abstract}
According to this study, approximately half of Africa's forests are utilized primarily or partially for the production of wood and non-wood commodities. Aims to evaluate Africa's forestry and forest products, namely Wood Forest Products (WFPs) and Non-wood Forest Products (NWFPs) in the sixteen (16) West African countries. While adhering to the following guidelines: wood extraction and preparation, analyzing wood primarily used as an energy source in Africa, identifying non-wood forest products in Africa, the state of export, trade, and customs procedures in West Africa, and examining the role of forests and forest stakeholders in Africa's low-carbon economy transition. An exploratory literature review of selected wood forest products and non-wood forest products (plants and animals) in West Africa identifying the country, the natural land area with the natural habitat issues of the forest, the species most harvested and traded in the West African sub-region. The study reemphasized some government legislation, policies, and market trade failures and limitations while also stating that trees may help in the low-carbon revolution through interventions aimed at maintaining, improving, and restoring natural capital have demonstrated that high environmental requirements of sustainable forest management (SFM) may be met in both natural and planted forests. The study identified a systematic assessment of the most common forest products (wood and non-wood forest products) considering the available data on the national forest reserves of the selected countries in West Africa. The study also revealed the need for biodiversity conservation of the available forest reserves to help mitigate the impact of global warming targeting the United Nation's Sustainable Development Goal 13- Climate Action. Which is focused on integrating climate change mitigation, adaptation, impact reduction, and early warning signs into the national policies, improving forest planning and management education, awareness-raising, and institutional capacity within the sub-region.
\end{abstract}

Keywords: forestry; forest management; forest products; land-use; West Africa.

\section{Introduction}

Forests in West Africa are being destroyed and forest products are being exploited at an alarming rate [1,2]. Land degradation has ensued as a result of this, with the Food and Agricultural Organization (FAO) of the United Nations [3,4] stating that Africa's annual rate of deforestation exceeds 4.5 million hectares, or 0.65 percent annually, despite the dire situation in certain regions. Between 2000 and 2005, the FAO observed a huge reduction of the natural vegetation of 4.3 percent in Togo, 3.5 percent in Nigeria, and 2.5 percent in Ghana [4]. Forest harvesting, unsustainable resource activities (e.g., removals 
or cocoa cultivation), wildfires, mining activities, and political upheaval have all contributed to a major reduction in the nature reserve. Forest destruction continues, resulting in biodiversity degradation for morphological and anatomical as well as floristic features, reducing vegetation and society - having to respond to worldwide forces of change; species diversity has amplified desertification, resulting in deteriorated farm yields and, as a result, deterioration of sparsely populated community livelihoods [5,6]. If the woods are not removed and converted to other land uses, the plant cover will be damaged or destroyed [7]. This analysis demonstrates that the cultivation of timber as well as non-wood forest resources has consumed almost 3 billion hectares of the land area throughout the world.. Brazil, Canada, and the United States of America are some countries in the West while China, India, Malaysia, Russia, and the European Union are also noted for the production of round-wood forest products. Landscape degradation, evasive desertification mostly due to climate change are some of the environmental crisis that has subjected the rainforest of Africa to strong and diverse pressures.

Today, rising demand for environmental assets as a consequence of human disruptions impacts, and frequently interrupts, Africa's renewal mechanism, resulting in the rapid spread of secondary forests in the forest zone of West Africa [4,6]. FAO opined that secondary woodlands accounted for 98 percent, 96 percent, and 95 percent of total forest cover in Guinea, Liberia, and Benin, respectively, in 2005 [4]. Many countries, on the other hand, have implemented legislation prohibiting log export to stimulate domestic processing and value-adding. The wood trade in Western Africa is influenced by local, regional, and worldwide demand, with Europe being an important market for the region's top producers. However, due to log export bans, most West African countries have rendered the trade in timber resources illegal. Low-cost hectic and poor timber lumbering for building and joinery are in high demand in the region, with regional markets giving an additional incentive in unlawful axe harvesting. This research looks at African forestry and forest products in terms of both timber and non-wood forest resources in West Africa. Wood harvesting and processing in West Africa, wood as a primary source of energy in Africa, non-wood paper manufacturing trade in Africa, exportation and customs procedures in West Africa, and the role of natural vegetation decision-makers in a low-carbon economy transition in the sub-region are among the issues discussed.

\section{The Review of Forest Products in Africa}

Africa's forest and wooded land cover 680 million hectares almost 400 million hectares, respectively, accounting for approximately 40 percent of the region's total surface area [8,9]. Humid subtropical rainforests in West Africa, drought-prone forests in Sub-saharan Africa, along with the Miombo woods of Tanzania and Mozambique, and Mediterranean forests and woodland in North Africa are also included (10-12).

\subsection{Forest Products Strategies}

This review examines the different strategies which the Continent's reserves are presently used to aid prosperity. It evaluates future demand patterns for forest goods and services, as well as the implications for forest resources, to highlight the key threats to the protection and conservation basis upon which the green growth initiatives rely [10].

\subsubsection{Harvesting and Processing of Wood}

From huge global firms to small and midsize enterprises and unofficial operations, Africa's wood harvesting and processing sector have it all. The formal wood harvesting and processing industry generates around US\$17 billion per year and contributes to a little less than $2 \%$ of Africa's GDP [4]. Forestry and logging activities have contributed to less than two-thirds of Africa's GDP through recent years, with timber processing - sawn wood, wood-based panels, and paper production - accounting for less than a third. Ap- 
proximately 700 thousand people, or 0.25 percent of the total, work in the organized economy. While the value of the formal forest sector's production in Africa has grown in fact from the 1990s, its relative monetary importance in African economies has fallen, owing to the growth of some of the other industries such as resource exploitation. In the 1990s, the official timber industry provided 2.0 percent of Africa's gross domestic products (2.2 percent in the region), but by 2006, it had dropped to 1.3 percent, and by 2011, it had dropped to 0.9 percent [13]. Nonetheless, there is significant regional heterogeneity, with the contribution to GDP in Liberia reaching 15\% [14,15], and the formal forest industry in Cameroon contributing more to GDP and state income in 2008-2010 than the mining sector [16].

\subsubsection{Forest Products as the Mostly Utilized Source of Energy}

Rather than lumber, the majority of Africa's round-wood production and consumption (about 95\%) is for wood fuel, such as fuel-wood and charcoal. In 2011, 63 percent of the African population, 80 percent of rural families, and 45 percent of city dwellers used wood or charcoal for cooking, according to FAO [4]. However, there are concerns about the nature of labour in the wood-fuel business, particularly in the production of charcoal. Because charcoal manufacturing is illegal in many African countries, the majority of the activity takes place behind closed doors, rather than to ensure that those involved in the wood collection and charcoal production are abiding by the regulations.

Since charcoal manufacturing is illegal in many African countries, the majority of the business operates beneath the surface, rather than to verify that those involved in firewood collection and fuelwood are paid fairly and work in safe circumstances [17-20]. Other social issues include the health implications of interior smoke emitted through the use of fuel-wood and wood chips burners, as well as the substantial measure of hours mothers and their kids spend collecting fuel-wood [21-23]. Firewood refers to circular wood that is used for frying, warming, or electricity production, as well as wood that is used to make wood chips. The FAO supplied a percentage figure and a description of wood-fuelled vehicles [21]. Wood-fuel figures must be interpreted carefully since several countries regularly report timber and coal output, hence most African countries rely on estimates [17]. The FAO's estimates of wood fuel and charcoal use are based on a statistical model that ties consumption to a variety of factors including demographics, revenue, natural vegetation, gas production, climate, and landmass [4,24].

\subsubsection{Non-wood Forest Products in Africa}

Many instance research on various locations seems to have the usefulness of quasi forest resources also referred to as non-wood forest products (NWFPs) for people's lives in the region, both sold and unmarketed, including exotic edibles and animal feeds is perhaps the most important applications after fuelwood [25-27]. NWFPs are commercially important, according to FAO [4], with a total production value of US\$5.3 billion in Africa in 2011, or 0.3 percent of GDP. These evaluations focused on medicinal plants, as well as a range of meat NWFPs (bush meat and beeswax/honey) and tree NWFPs (obtained from the fruit nuts, organic glue, and synthetic polymers). Regional employment data are rare in the NWFPs [28,29]. On the other hand, case studies of individual products can shed light on the relevance of NWFPs [24].

A production process for Prunus Africana, whose bark is an essential commodity for the pharmaceutical companies, exists in Cameroon, involved in at least 65,000 people in communities with community forests, plus individuals with plantations, approximately five hundred harvesters, ten exploitation permit-holding small scale enterprises, and approximately five exporting enterprises [30]. Although commercialized NWFPs could provide money and jobs for the local population, they face the same difficulties as wood fuel in terms of exploitative labour conditions and low collector returns. In some cases, 
this is due to illegal and indiscriminate harvesting, misuse, and abuse, while in others, it is due to collectors' absence of expertise and bargaining ability [25, 27] (see Figure 1; a-d).

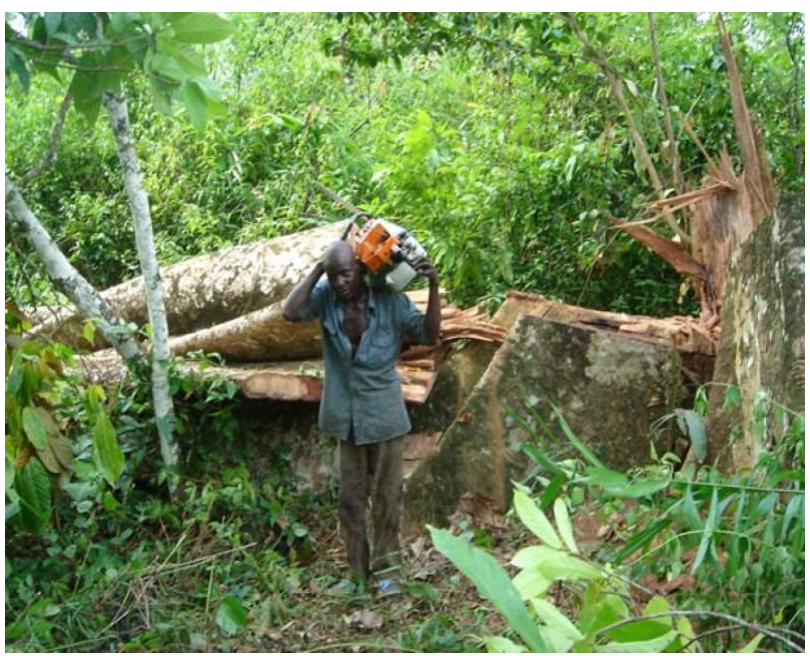

(a)

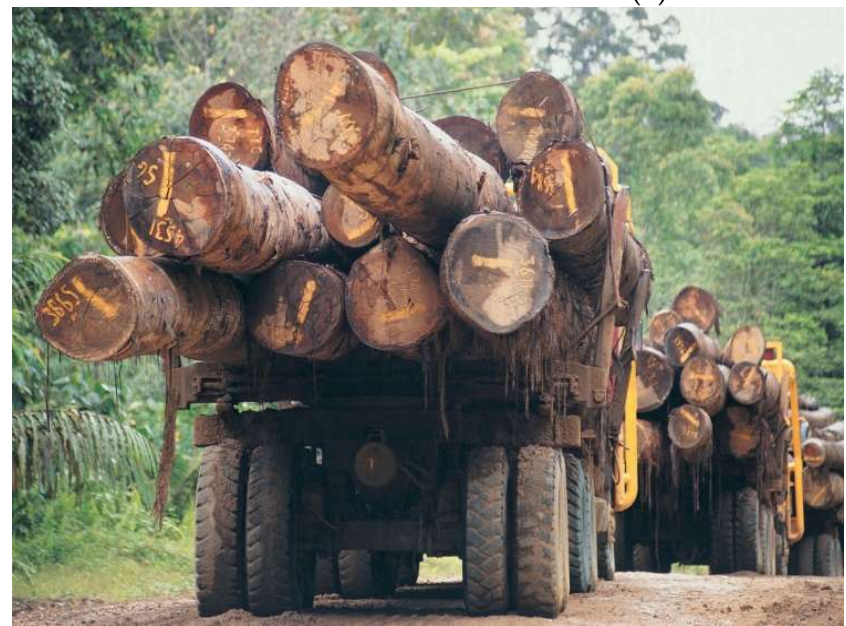

(c)

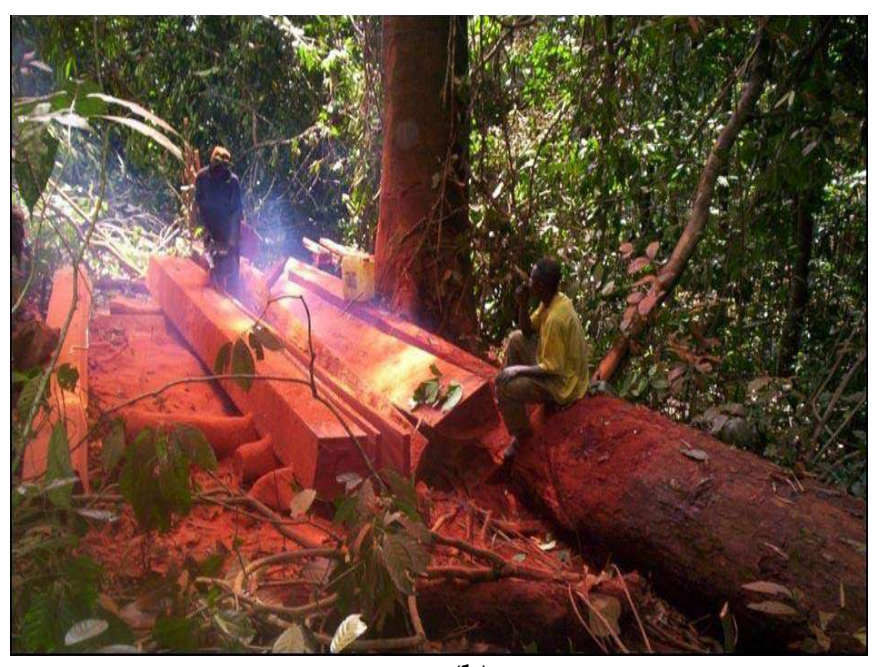

(b)

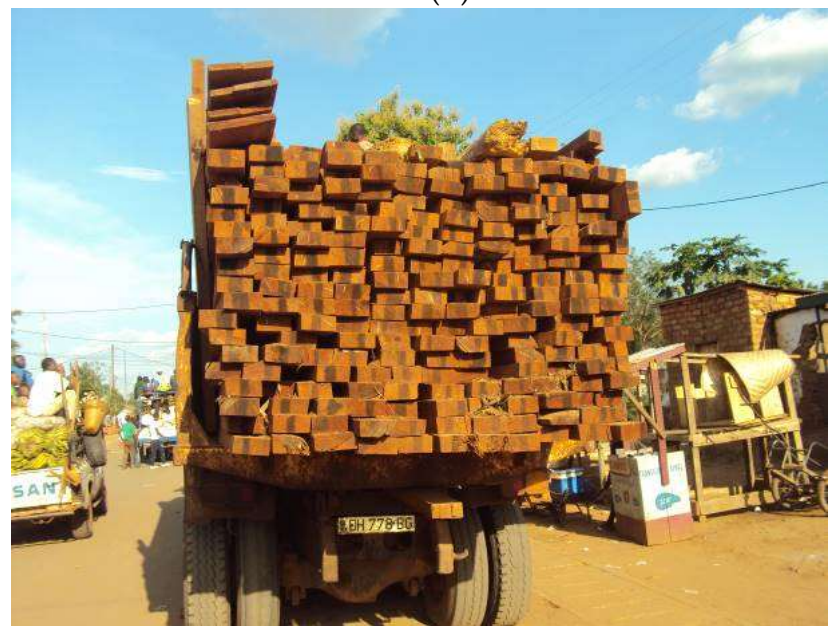

(d)

Figure 1. (a) Illegal harvest of wood products in South-west Nigeria. (b) Illegal harvest (sawn into regular sizes for easy carriage) of wood products in South-west Nigeria. (c) Trucks transporting illegally harvested wood products to the capital city of Bangui in the Central African Republic (CAR) [38]. (d) The illegally harvested wood products are now ready to be taken to the carpenters for further action $[37,38]$.

\subsubsection{Shifts of Forest Products Throughout the Sub-region}

Plywood via Ghana to Benin, Nigeria, and Togo, sawn-timber from the Ivory Coast through Ghana towards the Sahel, logs with plywood from Cameroon into northern Nigerian states, and logs and hardwood from Cameroon to northern Nigerian states. Timbers from Guinea Conakry and Liberia to Ivory Coast, sawn-timber from Sierra Leone to Guinea Conakry, sawn-timber from Ghana and Nigeria to Benin and Togo, sawn-timber from Nigeria and Ghana to Benin and Togo, sawn-timber from Nigeria and Ghana to Benin and Togo, sawn-timber from Nigeria and Ghana to Benin and Togo, hardwood from Nigeria and Ghana to Benin [31,32]. European markets, the US, China, and India are all key destinations for wood exports, with buyers from the latter two countries becoming more active in the region. Customers from India are particularly interested in Tectona grandis sawn-timber and poles, while Chinese consumers are interested in a variety of trees, notably false-teak, as well as Triplochiton scleroxylon, or vene logs and sawn timber [32-34]. 


\subsubsection{Trends in Wood Products Production in Nigeria}

In Nigeria, there are limited accurate estimates of output for wood and non-wood forest products [33]. Popoola 36], on the other hand, estimated that Nigeria's industrial round and woodfuel removals were worth US\$124 million and US\$456 million, respectively. This emphasizes the significance of wood fuel in the country's household cooking energy source. It also raises concerns about the necessity to focus purposeful efforts at both the government and private sector levels on the creation of fuelwood species plantings. It enables public-private partnerships in forest management. Private woodlots for fuelwood production are already in place at companies like the British-America Tobacco Company (BAT). The government might work with such groups by offering them advantages such as easy access to land, tax breaks, and technical assistance [36].

Fuel-wood use is anticipated to fall in absolute and per capita terms [36]. As living standards rise, this reflects a well-established and universal trend for more efficient and convenient fuels to replace fuelwood. With the decline in per capita GDP and the lack of alternative domestic fuels, this trend may not continue, and more people may be forced to rely on fuelwood in the future. This may be mitigated by Goal 8 of the SDGs, which focuses on cheap and sustainable energy. Poles, pilings, and posts are all used in construction. In terms of overall consumption, the continuous activities of low artisans been trained in carpentry works had increased in the past two decades (see Figure 2) therefore the expected shift implies minor rises by 2030 [4, 37].

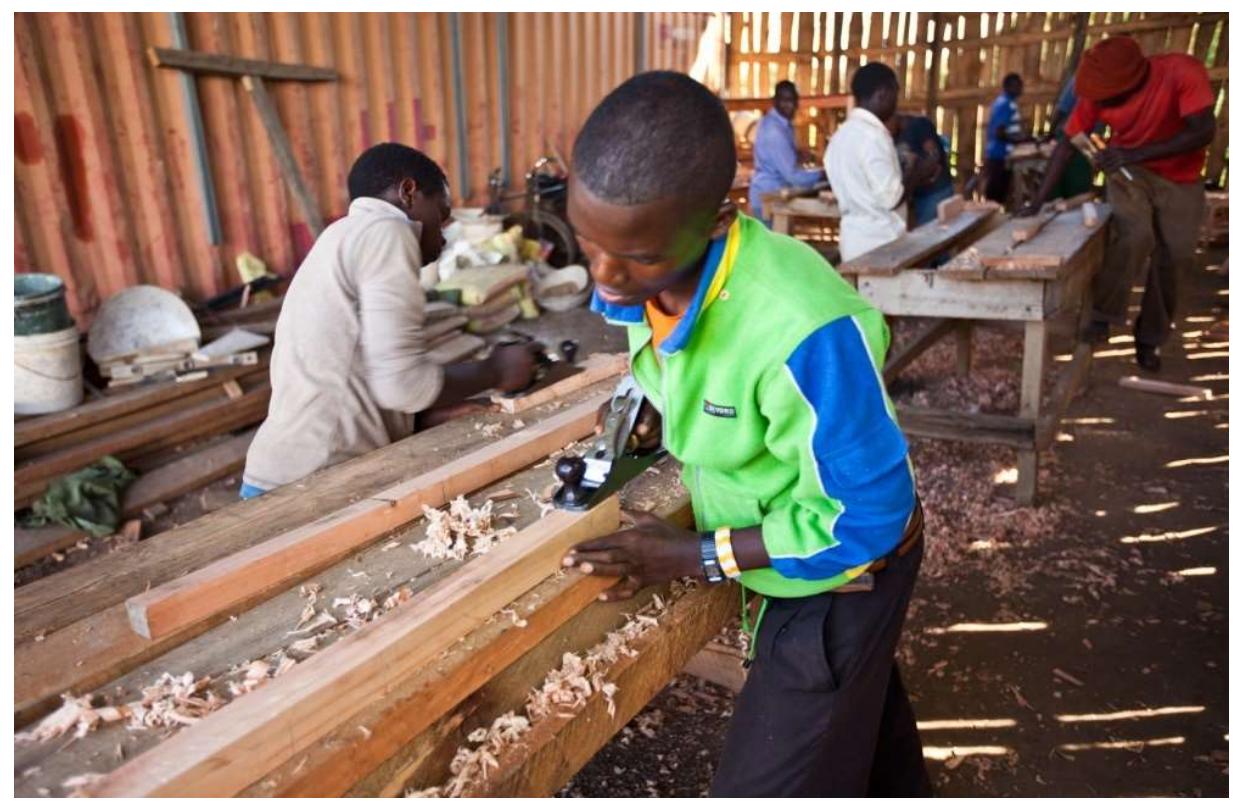

Figure 2. Low skilled workers getting trained in carpentry in a wood workshop [4].

Over the next ten years, demand for plywood will rise in both absolute and per capita levels. The cumulative rate of change in demand is expected to be as high as $217.45 \%$. This is faster than the rate of change in sawn wood demand over time. This confirms previously observed trends in processed forest products. It also reflects the technological advantages of more highly processed materials due to predicted advancements in utilization technology across time. Plywood is predicted to be manufactured in greater numbers as a result of technological advancements and dwindling forest productivity. This growth in the panel product sector will encroach on the sawn wood business $(34,36)$. 


\subsection{Export and Customs Procedures in West Africa}

Several West African countries have serious implementation issues and large opportunities to defy standards and suggested practices. As a result of the aforementioned condition, the national availability of cheap and reduced wood and particleboard has increased dramatically. A large portion of that kind of demand would be for West African construction industries, as well as Sahel countries that lack timber and processing firms. Deregulation of wood harvesting, transportation, trade, and industry is aided by the difficulty of implementing control and popular perceptions that illegal behaviour is acceptable [3].

\subsubsection{Timber Product Trade and Regional Needs}

Genuine domestic demand has gone unsatisfied due to a discrepancy in buying power between domestic and regional markets, as well as the concomitant over-concentration of effort on capitalizing on the export trade's potential. As a result, home markets in rapidly urbanizing countries such as Togo, Ghana, The Gambia, The Federal Republic of Nigeria, particularly civil war-ravaged Sierra Leone and Liberia are virtually entirely purchased illegally [32-35].

In Liberia, combining profitable foreign market possibilities with household consumption in a tiny economy with limited demand for goods and services remains a major challenge. A consistent strategy framework is essential to give appropriate information on local, national, and transboundary trade, as well as their effect on the sub-region. As a consequence, the forestry sector will benefit from proper evaluation and accountability. To satisfy contemporary demands, the sub-regional forestry authorities' enforcement, negotiation, information generation, and sharing abilities must be upgraded.

Tight government regulations across the woodland, underpinned through its position as a critical national asset, must give way to opportunity techniques that promote a steady flow of wood, forest resources, and commodities while transferring responsibility to communities and landowners.

\subsubsection{Management and Uses of Forests in West Africa}

Merely three of the selected Sixteen West African countries provided information upon that nature reserve encompassed by a regular, formally recognized forest service and management program. Of these countries, Benin-Togo had the least percentage $(2.1 \%)$ while Côte d'Ivoire seemed to have the most (19\%). According to Nigerian statistics, a management plan covers approximately 850000 hectares (approximately 10\%) of the country's natural forest (lowland rain forests alone). Natural forest harvesting and management have a long history in the humid region of West Africa. Several alternative subtropical conservation agriculture systems (e.g. tropical hardwood, altered sampling) have been investigated mostly in the background to improve production [4].

For both ecological and management reasons, these silvicultural practices have not always been effective [4; Dupuy et al. 1999). Government forestry agencies oversee the right to utilize timber in all nations in the subregion with tropical humid forests. Regulations outline the logging techniques and systems that are most suitable. The government grants private timber businesses or individuals concessions and issues contracts outlining the restrictions and procedures to be followed, which may include restocking and post-harvest activities in some situations. However, due to a lack of resources, official monitoring and control are frequently insufficient. Agreements and contracts are in place for forest plantations to control their utilization and avoid disputes $[4,30]$.

The existing literature did not identify the peculiarity of each West African country as it affects their ecosystem service and rural/urban air quality. However, it is noteworthy 
in this study that each of the identified countries (16) grossly have diverse and unique ecosystem services predominantly and justifiably situated, which have been degraded and lost due to so many forest issues- soil erosion, desertification, scarcity of freshwater resources, forest encroachment, and degradation. This will help further scientific studies in the area of calculating the carbon storage and carbon sequestration capabilities of the available forest in the WA region with emphasis on each of the 16 selected.

\subsection{Study Area: West Africa Sub-Region}

The word "West Africa" does not have a universal definition. As defined by the General Assembly of the United Nations, West Africa is the continent's westernmost region, consisting of 16 states countries and with a total area of little over 6 million $\mathrm{km} 2$. It has boundaries with North Africa to the north and Central Africa to the southeast. West Africa runs through Mauritania throughout the northwest to Nigeria mostly in the southeastern wing, like a belt. Figure 6 is a map of West Africa depicting forest product traffic in and out of the sub-region. The nations along the Atlantic Ocean's shoreline are all lined with infrastructure that allows for the export of forest timber and commodity items both within Africa and to other continents.

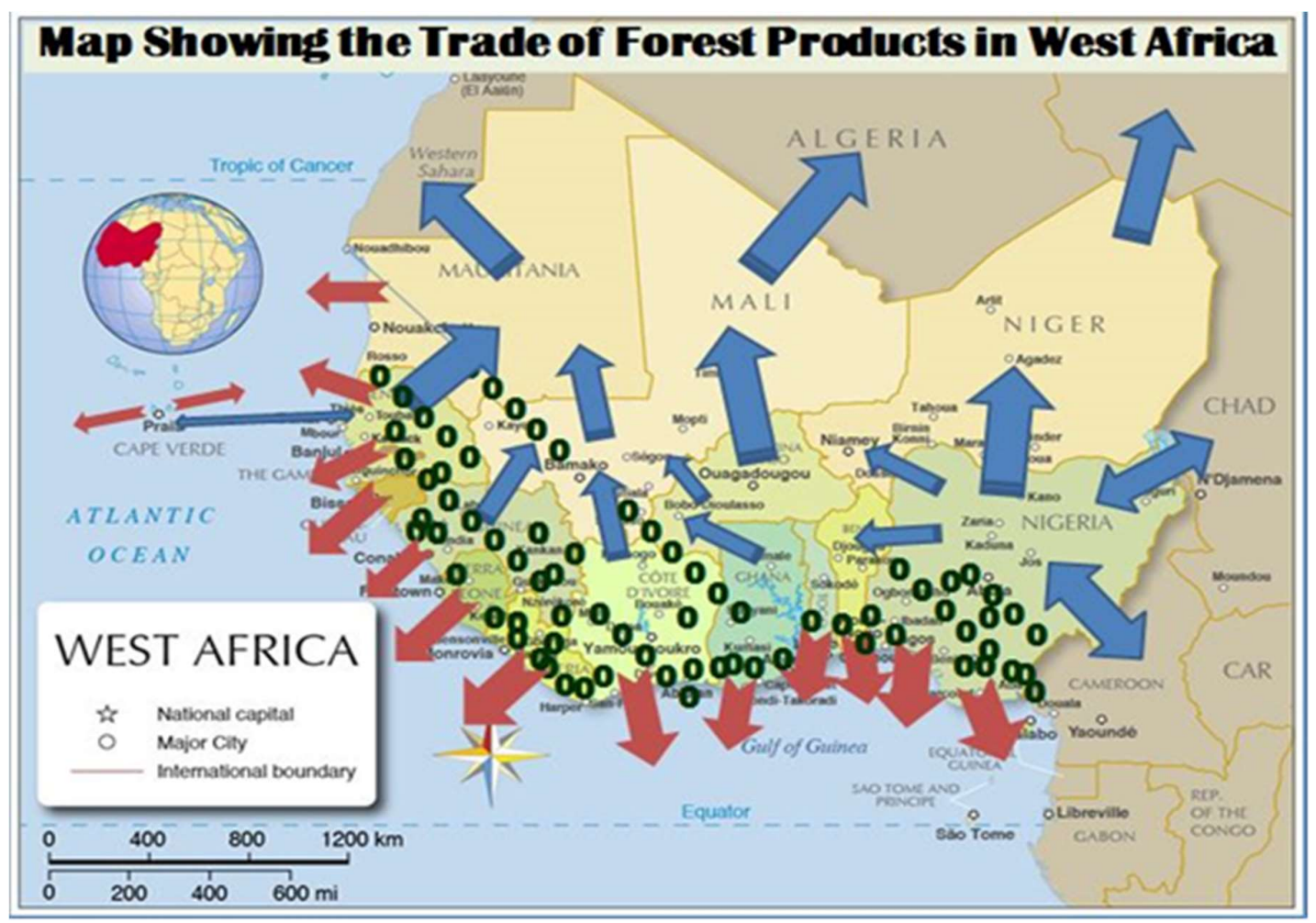

Figure 3. Map of Africa showing the wood products trades within the WA Sub-region. Note the directional signs- the blue arrows show the interregional trades mostly going up from the down below in an upward direction, while the red arrows show the intercontinental trades through the Atlantic Ocean-Golf of Guinea and the green dots show the dominance of forest products in the WA sub-region.

The West Africa sub-region also enjoys both the export and import trades of forest and non-forest products. The map (Figure 6) reveals the trades of forest products within West Africa and the other regions of Africa and some to other continents of the world as shown by the directional signs showing forest products leaving the borders of the selected countries into other countries (the blue arrows showing the interregional trades mostly going up from the down below in an upward direction, while the red arrows showing the intercontinental trades through the Atlantic Ocean-Golf of Guinea and the 
green dots shows the dominance of forest products in the WA sub-region). In certain FAO publications, the Sahelian nations of Burkina Faso, Mali, Mauretania, and Niger are classified as North Africa rather than West Africa in the Global Forest Resources Assessment [4,8]. West Africa is made up of 16 countries that stretch first from the West Sahel-savanna zone to the Guinea-Congolese zone in the southeast, divided by a climatic gradient. This subregion's tropical wet forests, dry forests, and savannah support a broad range of natural flora.

Tropical rain forests form a swath from Sierra Leone's eastern border to Ghana's. They span from eastern Benin to southern Nigeria as they scatter progressively along the River Volta. Woodlands may also be found in arid climates (tree and shrub savannah, parklands, and bush fallows). The Sahel's transition zone, as well as the regional center of Sudanese endemism, correspond to the dry portions of West Africa [39,40]. The humid zones of the Guinea-Congolese endemism core are included [40]. Two notable countries namely; The Gambia and Guinea-Bissau, on the other hand, are West Africa's smallest however most densely forested countries [41].

\section{Methodology}

This review study did an exploratory literature review of the Forestry and Forest Products Trade and Production considering the sixteen (16) countries West African subregion in Africa (Benin, Burkina Faso, Cape Verde, Côte d'Ivoire, Gambia, Ghana, Guinea, Guinea-Bissau, Liberia, Mali, Mauritania, Niger, Nigeria, Senegal, Sierra Leone, Togo). Within the worldview of the other sub-regions like; Northern Africa (Algeria, Egypt, Libyan Arab Jamahiriya, Morocco, Sudan, Tunisia), Eastern Africa (Burundi, Djibouti, Eritrea, Ethiopia, Kenya, Rwanda, Somalia, Uganda), Central Africa (Cameroon, Central African Republic, Chad, Congo, Democratic Republic of Congo, Equatorial Guinea, Gabon, Sao Tomé and Principe), Southern Africa (Angola, Botswana, Lesotho, Malawi, Mozambique, Namibia, South Africa, Swaziland, United Republic of Tanzania, Cairo, Zambia, Zimbabwe) and The Western Indian Ocean Islands (Comoros, Madagascar, Mauritius, Seychelles). While emphasizing on the Forestry and Forest Products in Africa- The Case of Wood and Non-wood Forest Products in West Africa. This review affirms the fact that the importance of wood in our homes, offices, shopping malls, and many other public uses cannot be overruled.

Table 1. Table showing the SWOT Analysis of the Wood Products and Non-wood Products in the West-Africa Sub-region.

\begin{tabular}{|ll|}
\hline \multicolumn{2}{|c|}{ S- Strengths } \\
\hline $\begin{array}{l}\text { 1. } \\
\text { 2. }\end{array}$ Lab creation for the youth and energetic young adults. \\
3. & Existence of policies for forest planning and management. \\
4. & Users' dependence on forest products and forests resources daily use. \\
5. & Adequate natural forests and non-forest products within the sub-region. \\
\hline \multicolumn{2}{c}{$\mathbf{W}$ - Weaknesses } \\
\hline 1. & Reduced production capacity. \\
2. & Here the state government owns the land and the forest. \\
3. & Infant saw-millers are most common around. \\
4. & The technology deployed in most cases is very low. \\
5. the government and individuals also invest very low into it. \\
6. & Extant National Forest Policy yet to be backed by any law. \\
\hline & O- Opportunities \\
\hline
\end{tabular}




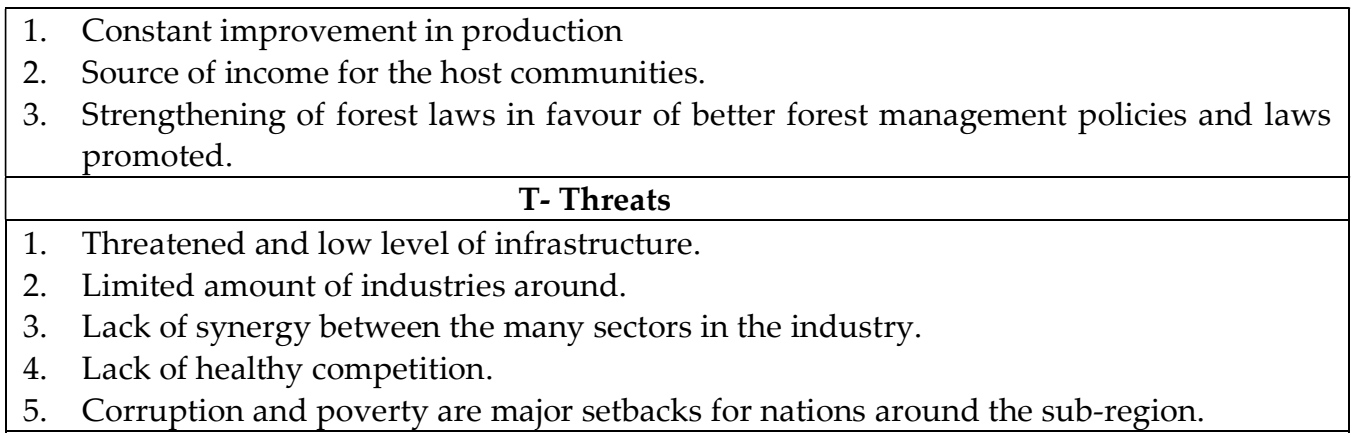

Table 1 explains the SWOT Assessment (Strengths, Weakness, Opportunities, and Threats) of the Sub-region as it relates to the Forestry and Forest Products Trade in Africa.

\subsection{The Variance of Forest Resources in West Africa}

The quality of forest resource knowledge and information differs by nation, according to this evaluation, which looked at a lot of literature. In most West African countries, data and statistics on forest resources and regions are obsolete, inaccurate, or incomplete. Some countries performed national evaluations of their natural forests in the 1990s (countries like Nigeria, Ghana, Benin, Burkina Faso, Guinea-Bissau, and The Gambia). Other West African countries had already completed national forest assessments (Senegal, 1985; Sierra Leone, 1986; Chad, 1988; Togo, 1975; Liberia, 1981). As a result, the forest areas presented (in Table 2) for numerous West African countries are based on literature-based national expert estimates. Table 2 shows that the total volume of West African forests is expected to be roughly 5.2 billion cubic meters overtime or around $12 \%$ of the total volume of African forests. The bulk of countries' estimates of volume and biomass are based on recent forestry surveys.

Table 2. Table showing the total surface area and natural surface distribution of the Sixteen Countries in West Africa.

\begin{tabular}{|c|c|c|c|c|}
\hline No & Country & $\begin{array}{l}\text { Total } \\
\text { Surface } \\
\text { Area (Ha) }\end{array}$ & $\begin{array}{l}\text { Natural } \\
\text { Forest }\end{array}$ & Forest issues \\
\hline 1 & $\begin{array}{l}\text { The Federal } \\
\text { Republic of } \\
\text { Nigeria }\end{array}$ & 91,077 ha & 12,824 ha & $\begin{array}{l}\text { Deforestation, Desertification, Second largest swamp } \\
\text { forest on the Continent (after Congolian swamp } \\
\text { forest). }\end{array}$ \\
\hline 2 & $\begin{array}{l}\text { Islamic } \\
\text { Republic of } \\
\text { Mauritania }\end{array}$ & 102,522 ha & 293 ha & $\begin{array}{l}\text { Soil erosion, Desertification, Scarcity of freshwater } \\
\text { resources, Forest degradation. }\end{array}$ \\
\hline 3 & $\begin{array}{l}\text { Republic of } \\
\text { Benin }\end{array}$ & 11,063 ha & 2,538 ha & $\begin{array}{l}\text { Rainforest destruction, In the north, it is prone to } \\
\text { drought. Degradation of the environment Protected } \\
\text { regions' long-term viability, Biodiversity is abundant. }\end{array}$ \\
\hline 4 & Burkina Faso & 27,360 ha & 7,023 ha & $\begin{array}{l}\text { Deforestation due to agricultural } \\
\text { Expansion, Loss of natural habitats }\end{array}$ \\
\hline 5 & $\begin{array}{l}\text { Republic of } \\
\text { Cabo Verde }\end{array}$ & 433 ha & 85 ha & $\begin{array}{l}\text { Continuous Soil erosion, Desertification in some parts } \\
\text { of the Island, Government effort on afforestation. }\end{array}$ \\
\hline 6 & $\begin{array}{l}\text { Republic of } \\
\text { Côte d'Ivoire }\end{array}$ & 31,800 ha & 6,933 ha & $\begin{array}{l}\text { Habitat destruction, soil degradation, and the largest } \\
\text { global intact natural forest land area }\end{array}$ \\
\hline
\end{tabular}




\begin{tabular}{|c|c|c|c|c|}
\hline 7 & $\begin{array}{l}\text { Republic of } \\
\text { Ghana }\end{array}$ & 22,754 ha & 6,259 ha & $\begin{array}{l}\text { Deforestation due to farming, urbanization, and } \\
\text { mining activities. }\end{array}$ \\
\hline 8 & $\begin{array}{l}\text { Republic of } \\
\text { Guinea }\end{array}$ & 24,572 ha & 6,904 ha & $\begin{array}{l}\text { Deforestation due to farming, urbanization, and } \\
\text { mining activities. }\end{array}$ \\
\hline 9 & $\begin{array}{l}\text { Republic of } \\
\text { Guinea-Bissau }\end{array}$ & 3,612 ha & 2,186 ha & $\begin{array}{l}\text { Deforestation due to farming, urbanization, and } \\
\text { mining activities. }\end{array}$ \\
\hline 10 & $\begin{array}{l}\text { Republic of } \\
\text { Liberia }\end{array}$ & 11,137 ha & 3,363 ha & $\begin{array}{l}\text { Has the largest forest reserve in West Africa, } \\
\text { Deforestation } \\
\text { Bush burning due to farm activities. }\end{array}$ \\
\hline 11 & $\begin{array}{l}\text { Republic of } \\
\text { Mali }\end{array}$ & 122,019 ha & 13,172 ha & $\begin{array}{l}\text { Deforestation due to farming, urbanization, and } \\
\text { mining activities. }\end{array}$ \\
\hline 12 & $\begin{array}{l}\text { Republic of } \\
\text { Niger }\end{array}$ & 126,670 ha & $1,256 \mathrm{ha}$ & $\begin{array}{l}\text { Desertification, Land degradation, afforestation of } \\
\text { agricultural land. }\end{array}$ \\
\hline 13 & $\begin{array}{l}\text { Republic of } \\
\text { Senegal }\end{array}$ & 19,252 ha & 5,942 ha & $\begin{array}{l}\text { Large forest areas, High Deforestation, continuous } \\
\text { Desertification. }\end{array}$ \\
\hline 14 & $\begin{array}{l}\text { Republic of } \\
\text { Sierra Leone }\end{array}$ & 7,162 ha & 1,049 ha & $\begin{array}{l}\text { Large forest areas, High Deforestation, continuous } \\
\text { Desertification. }\end{array}$ \\
\hline 15 & $\begin{array}{l}\text { Republic of } \\
\text { The Gambia }\end{array}$ & 1,290 ha & 479 ha & $\begin{array}{l}\text { Desertification, Land degradation, afforestation of } \\
\text { agricultural land. }\end{array}$ \\
\hline 16 & $\begin{array}{l}\text { Togolese } \\
\text { Republic }\end{array}$ & 5,439 ha & 472 ha & $\begin{array}{l}\text { High rate of human farm activities, Desertification, soil } \\
\text { degradation, afforestation of agricultural land. }\end{array}$ \\
\hline & Total & 733,359 ha & 83,369 ha & \\
\hline
\end{tabular}

Source: Partly adapted and modified from Landscapes of West Africa - A Window on a Changing World. U.S. Geological Survey [37].

Volume evaluation for fuelwood utilization in arid regions typically covers the complete mucilaginous content, comprising stems and leaves. Depending on rainfall and plant species, the natural landscape in Western Africa is expected to yield between 0.2 and $3.0 \mathrm{~m} 3$ per hectare per year (39]

Table 3. Table showing the production capacity evaluation of the Wood Forest Products.

\begin{tabular}{|l|l|l|l|}
\hline $\begin{array}{l}\text { Timber and Wood } \\
\text { Products }\end{array}$ & $\begin{array}{l}\text { Production } \\
\text { Capacity }\end{array}$ & Producers & Largest producer \\
\hline Wood Raw Material & $* * * *$ & $\begin{array}{l}\text { Nigeria, Côte d'Ivoire, } \\
\text { Ghana, Senegal, Guinea, } \\
\text { Cameroon }\end{array}$ & $\begin{array}{l}\text { Nigeria- Country holds a species } \\
\text { with a range size }>12,000 h a\end{array}$ \\
\hline Sawn Softwood & $*$ & $\begin{array}{l}\text { Côte d'Ivoire, Nigeria, } \\
\text { Ghana, Liberia }\end{array}$ & $\begin{array}{l}\text { Côte d'Ivoire- Country holds a } \\
\text { species with a range size } \\
>6,000 h a\end{array}$ \\
\hline Sawn Hardwood & $* * * *$ & $\begin{array}{l}\text { Nigeria, Côte d'Ivoire, } \\
\text { Ghana, Senegal, Guinea }\end{array}$ & All \\
\hline Wood-based Panels & $* * * *$ & Nigeria, Côte d'Ivoire, & All \\
\hline
\end{tabular}




\begin{tabular}{|l|l|l|l|}
\hline & & Ghana, Liberia & \\
\hline $\begin{array}{l}\text { Paper, Paperboard, } \\
\text { and Wood Pulp }\end{array}$ & $* * * *$ & Mali, Ghana, Nigeria & $\begin{array}{l}\text { Mali- Country holds a species } \\
\text { with a range size }>13,000 \text { ha }\end{array}$ \\
\hline $\begin{array}{l}\text { Rattan, Cane, and } \\
\text { Raphia }\end{array}$ & $* *$ & All 16 WA Countries & All \\
\hline Fuelwood & $* * *$ & All 16 WA Countries & Nigeria \\
\hline Bamboo & $* * *$ & $\begin{array}{l}\text { Nigeria, Côte d'Ivoire, } \\
\text { Ghana, Liberia }\end{array}$ & All \\
\hline Fibres & $* * *$ & $\begin{array}{l}\text { Nigeria, Côte d'Ivoire, } \\
\text { Ghana, Senegal, Guinea }\end{array}$ & All \\
\hline
\end{tabular}

Note the matrix used to assign priority scores to species-site combinations $4^{*}$ (Most Adequate), $3^{*}$ (Adequate), $2^{*}($ Fairly Adequate), 1*(Inadequate), 0 (Not Available).WA- West Africa. > Greater than, < Less than.

Indeed, the dispersed forest cover of most West African countries helps make such resource incredibly useful, especially in arid zones where a significant share of fuelwood is obtained outside the forest. The number of dry zones and scattered forests across farm areas contributes to roughly $35 \%$ of Burkina Faso's forest products and $20 \%$ of The Gambia's. Several non-governmental groups are trying to guarantee that biodiversity in protected areas is preserved for a longer period [8]. West Africa includes roughly 130 officially preserved places, according to the opinion of the World Conservation Monitoring Centre in 1997 [8,41].

Table 4. Table showing the production capacity evaluation of Non-wood Forest Products.

\begin{tabular}{|c|c|c|c|}
\hline \multicolumn{4}{|l|}{ Plant Products } \\
\hline Plant Products & $\begin{array}{l}\text { Production } \\
\text { Capacity }\end{array}$ & Producers & Largest producer \\
\hline Food products & $* * * *$ & All 16 WA Countries & All \\
\hline Fodders & $* * * *$ & All 16 WA Countries & All \\
\hline Fruits & $* * * *$ & All 16 WA Countries & All \\
\hline Ornamental flowers & $* * * *$ & All 16 WA Countries & Nigeria \\
\hline Utensils & $* * * *$ & All 16 WA Countries & The Gambia \\
\hline Handicrafts, & $* * * *$ & All 16 WA Countries & Ghana \\
\hline $\begin{array}{l}\text { Construction } \\
\text { materials (Thatch) }\end{array}$ & $* * * *$ & All 16 WA Countries & $\begin{array}{l}\text { Nigeria (Northern Nigeria in } \\
\text { particular) }\end{array}$ \\
\hline Dying and tanning & $* * *$ & Nigeria, Ghana & Nigeria \\
\hline Perfumes, cosmetics & $* *$ & All 16 WA Countries & All \\
\hline Mushroom & $* * * *$ & All 16 WA Countries & All \\
\hline Palm Wine & $* * * *$ & All 16 WA Countries & Nigeria \\
\hline Palm Oil & $* * * *$ & All 16 WA Countries & Nigeria \\
\hline Medicinal plants & $* * * *$ & All 16 WA Countries & Ghana \& Nigeria \\
\hline Cola Nuts & $* * *$ & All 16 WA Countries & Nigeria \\
\hline \multicolumn{4}{|l|}{ Animal Products } \\
\hline Living animals & $* * * *$ & All 16 WA Countries & All \\
\hline
\end{tabular}




\begin{tabular}{|l|l|l|l|}
\hline Honey & $* * * *$ & All 16 WA Countries & Nigeria \\
\hline Beeswax & $* *$ & All 16 WA Countries & Cameroun \\
\hline Bushmeat & $* * * *$ & All 16 WA Countries & All \\
\hline Hides and Skins & $* * * *$ & All 16 WA Countries & All \\
\hline Medicines & $* * * *$ & All 16 WA Countries & All \\
\hline Colourants & $* * * *$ & All 16 WA Countries & Nigeria \\
\hline
\end{tabular}

Note the matrix used to assign priority scores to species- site combinations $4^{*}$ (Most Adequate), $3^{*}$ (Adequate), $2^{*}$ (Fairly Adequate), 1*(Inadequate), 0 (Not Available).WA- West Africa. > Greater than, < Less than.

Table 5. Table showing the checklist of Forest Products in West Africa.

\begin{tabular}{|c|c|c|c|c|}
\hline Countries“' & $\begin{array}{l}\text { Wood } \\
\text { forest } \\
\text { products }\end{array}$ & $\begin{array}{l}\text { Non-wood } \\
\text { forest } \\
\text { products } \\
\text { (Plant } \\
\text { products) }\end{array}$ & $\begin{array}{l}\text { Non-wood } \\
\text { forest } \\
\text { products } \\
\text { (Animal } \\
\text { products) }\end{array}$ & $\begin{array}{l}\text { Remarks } \\
\text { (on the forest rating of } 2,000 \\
\text { ha) }\end{array}$ \\
\hline $\begin{array}{l}\text { Federal Republic of } \\
\text { Nigeria }\end{array}$ & $* * * *$ & $* * * *$ & $* * * *$ & $\begin{array}{l}\text { Wood Forest products }>2000 \text { ha. } \\
\text { Mostly adequate }\end{array}$ \\
\hline $\begin{array}{l}\text { Islamic Republic of } \\
\text { Mauritania }\end{array}$ & $* * *$ & $* * *$ & $* * *$ & $\begin{array}{l}\text { Wood Forest products }<2000 \text { ha. } \\
\text { Generally adequate }\end{array}$ \\
\hline $\begin{array}{l}\text { Republic of } \\
\text { Benin }\end{array}$ & $* * *$ & $* * *$ & $* * *$ & $\begin{array}{l}\text { Wood Forest products }>2000 \text { ha. } \\
\text { Generally adequate }\end{array}$ \\
\hline Burkina Faso & * & * & * & $\begin{array}{l}\text { Wood Forest products }>2000 \text { ha. } \\
\text { Generally inadequate }\end{array}$ \\
\hline $\begin{array}{l}\text { Republic of } \\
\text { Cabo Verde }\end{array}$ & * & * & * & $\begin{array}{l}\text { Wood Forest products }<2000 \text { ha. } \\
\text { Generally inadequate }\end{array}$ \\
\hline $\begin{array}{l}\text { Republic of } \\
\text { Côte d'Ivoire }\end{array}$ & $* *$ & $* *$ & $* *$ & $\begin{array}{l}\text { Wood Forest products }>2000 \text { ha. } \\
\text { Fairly adequate }\end{array}$ \\
\hline $\begin{array}{l}\text { Republic of } \\
\text { Ghana }\end{array}$ & $* * *$ & $* * *$ & $* * *$ & $\begin{array}{l}\text { Wood Forest products }>2000 \text { ha. } \\
\text { Generally adequate }\end{array}$ \\
\hline $\begin{array}{l}\text { Republic of } \\
\text { Guinea }\end{array}$ & $* * *$ & $* * *$ & $* * *$ & $\begin{array}{l}\text { Wood Forest products }>2000 \text { ha. } \\
\text { Generally adequate }\end{array}$ \\
\hline $\begin{array}{l}\text { Republic of } \\
\text { Guinea-Bissau }\end{array}$ & $* *$ & $* *$ & $* *$ & $\begin{array}{l}\text { Wood Forest products }>2000 \text { ha. } \\
\text { Fairly adequate }\end{array}$ \\
\hline $\begin{array}{l}\text { Republic of } \\
\text { Liberia }\end{array}$ & $* * *$ & $* * *$ & $* * *$ & $\begin{array}{l}\text { Wood Forest products }>2000 \text { ha. } \\
\text { Generally adequate }\end{array}$ \\
\hline $\begin{array}{l}\text { Republic of } \\
\text { Mali }\end{array}$ & $* * * *$ & $* * * *$ & $* * * *$ & $\begin{array}{l}\text { Wood Forest products }>2000 \text { ha. } \\
\text { Mostly adequate }\end{array}$ \\
\hline $\begin{array}{l}\text { Republic of } \\
\text { Niger }\end{array}$ & $* *$ & $* *$ & $* *$ & $\begin{array}{l}\text { Wood Forest products }<2000 \text { ha. } \\
\text { Fairly inadequate }\end{array}$ \\
\hline $\begin{array}{l}\text { Republic of } \\
\text { Senegal }\end{array}$ & $* * *$ & $* * *$ & $* * *$ & $\begin{array}{l}\text { Wood Forest products }>2000 \text { ha. } \\
\text { Generally adequate }\end{array}$ \\
\hline
\end{tabular}




\begin{tabular}{|l|l|l|l|l|}
\hline $\begin{array}{l}\text { Republic of } \\
\text { Sierra Leone }\end{array}$ & $* * *$ & $* * *$ & $\begin{array}{l}\text { Wood Forest products }<2000 \text { ha. } \\
\text { Generally adequate }\end{array}$ \\
\hline $\begin{array}{l}\text { Republic of } \\
\text { The Gambia }\end{array}$ & $* * *$ & $* * *$ & $* * *$ & $\begin{array}{l}\text { Wood Forest products }<2000 \text { ha. } \\
\text { Generally adequate }\end{array}$ \\
\hline $\begin{array}{l}\text { Togolese Republic } \\
\text { G** }\end{array}$ & $* * *$ & $* * *$ & $\begin{array}{l}\text { Wood Forest products }<2000 \text { ha. } \\
\text { Generally adequate. }\end{array}$ \\
\hline
\end{tabular}

Note: $4^{*}$ (Most Adequate), 3*(Adequate), 2*(Fairly Adequate), 1*(Inadequate), 0 (Not Avalaible). > Greater than, < Less than.

\section{Discussion: The West African Sub-Region Wood Production and Trade}

Africa's agriculture is mostly focused on domestic markets. Africa is also connected to global markets. A few nations have created cash crops (tropical goods) to export outside of Africa, mostly to the European Union, which gives them preferential trade treatment. African nations have been net importers of food and agricultural raw resources over the past two decades. Agriculture commerce in the region: complementarities and integration Intra-African trade in agricultural and food items are low: about $17 \%$ of African nations' overall international commerce was handled at the intra-regional level by the end of the 2000s. These products are also traded locally for home usage and consumption. Cross-border commerce consists of local product flows as well as import/export flows aided by techniques used to get over some nations' prohibitive restrictions against imports from the international market.

\subsection{Government Legislation, Policy, and Market Failures}

Other than wood fuel, non-wood forest resources provide a substantial portion towards the economy, accounting for around half of the total generated by wood and fibre production, as well as meeting critical basic requirements in hunger, healthcare, and society. Forests are rarely handled effectively, and deforestation and forest degradation are common occurrences. Forests provide regulatory, sustaining, and sociocultural environmental impacts that are essential for a healthy well-being and lie at the heart of a range of development industries, however, they are under-reported and hence receive less attention. Given Africa's likely population expansion and projected robust growth, the need for woodland products and services is expected to soar. It's possible that by 2050, wood items will be two to three times what they are now. Collection rates considerably beyond sustainable yield will be necessary to meet such demand from the present natural forest allocated for production, putting more pressure on the forest protection and conservation core, which is often threatened by intensive agriculture.

This might be worsened by localized wood fuel constraints. Even though planted forest output is likely to continue to rise, this will not be enough to close the supply gap. Meeting demand without considerably increasing import reliance will become increasingly difficult if the forest area's economic base advances to decline as a result of degradation and exploitation. This will almost certainly result in a significantly reduced forest sector, with less employment, a greater reliance on imports, and the replacement of wood with potentially more environmentally damaging items. As harvesting intensity hits critical levels, the result of such an excessive quantity demanded, as well as demands from other sectors, such as agriculture, would jeopardize forests' capacity to provide essential ecological services: burning of fossil fuels will increase, and diversity will indeed be threatened.

\subsection{Green Economy}


Some have been tried in different parts of the sub-region, and they demonstrate how trees may contribute to a green economy revolution. Significant ecological standards of forest conservation that are sustainable (like the sustainable forest management strategies- SFM) may be satisfied both in indigenous and cultivated rainforests, according to interventions targeted at preserving, enhancing, and restoring natural resources. It may be more difficult to manage social relations and provide long-term advantages for local communities. So far, the results of interventions have been uneven. It's vital to take classes and make adjustments along the way. New technologies, improved handling and storage methods, and supply chain structure, according to another set of interventions, can considerably increase resource productivity in the plant, wood processing, coal manufacture, including kitchen ovens. Although this has the potential to reduce pressure on forest resources, achieving high levels of adoption and overcoming budgetary constraints will be difficult.

\section{Conclusions}

Most West African countries have adopted comprehensive forest management strategies that embrace the overall concept of sustainable forest management, or are in the process of doing so. Despite this, some nations lack sufficient and technical means to carry out these projects effectively. In general, forestry initiatives are underfunded. As a result, most forestry institutions in West African countries are ill-equipped to carry out their duties. Most of these countries' forest resource data is erroneous, outdated, and in need of updating. Many countries have the administrative and technical capacity to carry out forest-planting initiatives. Plantation upkeep and commercialization, on the other hand, are influenced by a lack of financial resources. Forest resources in West Africa are under stress due to a variety of factors, including rapid population growth, economic development, poverty, and regulatory frameworks, and lack of equal enforcement distributions at all administration levels in some countries, lack of adequate information on forests, poor project execution, etc.

Failure to recognize native populations' and other local societies' legal rights to their lands can also result in deforestation and continuous exploitation and degradation. This, along with a lack of land protection, often leads to an open access situation where no one or institution is liable for such assets.

Forest degradation and refugee settlement in forested areas have occurred from violence in various West African nations (Nigeria, Liberia, and Sierra Leone). As a result of urban population growth, timber harvesting as forest products, building supplies, and farmland for habitation sometimes leads to deforestation in the immediate area. Deforestation is mostly caused by agribusiness and inefficient agricultural methods (crop rotation and agricultural goods), lumbering (poor extraction practices, weak leasing contracts, etc.), as well as other land-use activities such as urbanization and mineral extraction. Forests in the sub-region have been over-harvested for timber.

The replacement of cash crops with tree plantations is one of the leading causes of deforestation in humid forests. Vast areas of rainforests have already been cleared in locations like Côte d'Ivoire for producing cash crops like coffee, sugar trees, and latex. Wildfires are among the most significant challenges to long-term forest planning, preservation, restoration, and management.

Domestic furniture is only one of the items derived from trees that make life on Earth considerably more bearable, according to the conclusion of this article. Abuse of deforestation and forest product exploitation, on the other hand, may be destructive to the ecosystem while also diminishing the rich biodiversity of West Africa's forests. Reg- 
ulation, as well as the execution of regulations on the use of forest products, must be tightened and monitored.

Author Contributions: A. J. prepared the introduction, literature review, conceptualization, methodology, and writing of the manuscript. J. Z. and T. X. reviewed and revised the manuscript to this present form. A. J., J. Z., and T. X. have all read and agree to the published version of the manuscript. All authors provided editorial advice and participated in the review process.

Funding: This research received no external funding.

Acknowledgements: The authors acknowledge the valuable comments and suggestions made by the reviewers and also express sincere appreciation to the editorial team (MDPI Forests Journal) for reviewing this manuscript

Conflicts of Interest: The authors declare no conflict of interest.

\section{References}

1. Caillault, Sébastien, Paul Laris, Cyril Fleurant, Daniel Delahaye, and Aziz Ballouche. "Anthropogenic Fires in West African Landscapes: A Spatially Explicit Model Perspective of Humanized Savannas." Fire 3, no. 4 (2020): 62. https://doi.org/10.3390/fire3040062.

2. Liu, Xue, Temilola E. Fatoyinbo, Nathan M. Thomas, Weihe Wendy Guan, Yanni Zhan, Pinki Mondal, David Lagomasino et al. "Large-scale High-resolution Coastal Mangrove Forests Mapping across West Africa with Machine Learning Ensemble and Satellite Big Data." Frontiers in Earth Science 8 (2021): 677. https://doi.org/10.3389/feart.2020.560933

3. KWAWUVI, D., E. BESSAH, and GK OWUSU. "AN OVERVIEW OF FOREST CONSERVATION STRATEGIES IN GHANA." Ethiopian Journal of Environmental Studies \& Management 14, no. 1 (2021): 23-46. doi: https://ejesm.org/doi/v14i1.3

4. FAO, I. ISRIC, 2006. World Reference Base for Soil Resources. A Framework for International Classification, Correlation, and Communication. Food and Agricultural Organization of the United Nations, International Union of Soil Sciences and International Soil Reference and Information Centre. Rome, Italy. World soil resources report NO, 103, 67-97. http://hdl.handle.net/10068/310015.

5. Peñuelas, Josep, and Jordi Sardans. "Global Change and Forest Disturbances in the Mediterranean Basin: Breakthroughs, Knowledge Gaps, and Recommendations." Forests 12, no. 5 (2021): 603. https://doi.org/10.3390/f12050603.

6. Pérez-Izquierdo, L., Laurent Saint-André, Philippe Santenoise, Marc Buée, and A. Rincón. "Tree genotype and seasonal effects on soil properties and biogeochemical functioning in Mediterranean pine forests." European journal of soil science 69, no. 6 (2018): 1087-1097. https://doi.org/10.1111/ejss.12712.

7. Fairhead, James, and Melissa Leach. Webs of power and the construction of environmental policy problems: forest loss in Guinea. Routledge, 2020. https://www.taylorfrancis.com/chapters/edit/10.4324.

8. FAO, 2010. What Woodfuels can do to Mitigate Climate Change? FAO Forestry Paper 162.Food and Agriculture Organization of the UN. Rome, Italy. http://www.fao.org/docrep/013/i1756e/i1756e00.htm.

9. Johnson, F., P. Tella, A. Israilava, T. Takama, R. Diaz-Chavez, and F. Rosillo-Calle. "What woodfuels can do to mitigate climate change (FAO Forestry Paper)." (2010). http://www.fao.org/docrep/013/i1756e/i1756e00.htm.

10. Blackie, Reuben, Cristina Baldauf, Denis Gautier, Davidson Gumbo, Habtemariam Kassa, Narayanaswamy Parthasarathy, Fiona Paumgarten et al. Tropical dry forests: The state of global knowledge and recommendations for future research. Vol. 2. Cifor, 2014. https://books.google.com.ng/books?hl=en\&lr=\&id.

11. Sunderland, T., D. Apgaua, Cristina Baldauf, Reuben Blackie, C. Colfer, A. B. Cunningham, K. Dexter et al. "Global dry forests: a prologue." International Forestry Review 17, no. 2 (2015): 1-9. DOI: https://doi.org/10.1505/146554815815834813.

12. Portillo-Quintero, Carlos, Arturo Sanchez-Azofeifa, Julio Calvo-Alvarado, Mauricio Quesada, and Mario Marcos do Espirito Santo. "The role of tropical dry forests for biodiversity, carbon and water conservation in the neotropics: lessons learned and opportunities for its sustainable management." Regional Environmental Change 15, no. 6 (2015): 1039-1049. DOI: https://doi.org/10.1007/s10113-014-0689-6.

13. Schmidt, Goran. "Industrialized bamboo in East Africa: Resource, production process and the market entrance of a novel scriber composite." PhD diss., Staats-und Universitätsbibliothek Hamburg Carl von Ossietzky, 2020. https://ediss.sub.uni-hamburg.de/handle/ediss/8720.

14. Hasselberg, Astrid Elise, Inger Aakre, Joeri Scholtens, Ragnhild Overå, Jeppe Kolding, Michael S. Bank, Amy Atter, and Marian Kjellevold. "Fish for food and nutrition security in Ghana: Challenges and opportunities." Global Food Security 26 (2020): 100380. https://doi.org/10.1016/j.gfs.2020.100380.

15. Guttal, Shalmali. "Re-imagining the UN Committee on World Food Security." Development (2021): 1-9. DOI: https://doi.org/10.1057/s41301-021-00322-z.

16. Riggs, Rebecca Anne, James Douglas Langston, Lauren Nerfa, Agni Klintuni Boedhihartono, Chris Gaston, Adinda Rizky Herdianti, Emilio Valeri, and Jeffrey Sayer. "Common ground: integrated landscape approaches and small and medium forest 
enterprises for vibrant forest landscapes." Sustainability Science 16, no. $6 \quad$ (2021): $2013-2026 . \quad$ DOI: https://doi.org/10.1007/s11625-021-01035-5.

17. Alfaro, Jose F., and Brieland Jones. "Social and environmental impacts of charcoal production in Liberia: Evidence from the field." Energy for Sustainable Development 47 (2018): 124-132. https://doi.org/10.1016/j.esd.2018.09.004.

18. Rodrigues, Thaisa, and Aldo Braghini Junior. "Technological prospecting in the production of charcoal: A patent study." Renewable and Sustainable Energy Reviews 111 (2019): 170-183. https://doi.org/10.1016/j.rser.2019.04.080.

19. Doggart, Nike, and Charles Meshack. "The marginalization of sustainable charcoal production in the policies of a modernizing African nation." Frontiers in Environmental Science 5 (2017): 27. https://doi.org/10.3389/fenvs.2017.00027.

20. Santos, Sueli de Fátima de Oliveira Miranda, and Kazuo Hatakeyama. "Sustainable charcoal production process focusing the environmental, economical, social and cultural aspects." Production $22 \quad$ (2012): 309-321. https://doi.org/10.1590/S0103-65132012005000010.

21. World Bank. Scaling-up access to clean cooking technologies and fuels in sub-Saharan Africa. World Bank, Washington, DC: 2012. Available athttp://siteresources._AFREA_AFTEG_ESMAP_FINAL.pdf.

22. Njoh, Ambe J. "The SWOT model's utility in evaluating energy technology: Illustrative application of a modified version to assess the sawdust cookstove's sustainability in Sub-Saharan Africa." Renewable and Sustainable Energy Reviews 69 (2017): 313-323. https://doi.org/10.1016/j.rser.2016.11.049.

23. Hancock, Kathleen J. "The expanding horizon of renewable energy in sub-Saharan Africa: Leading research in the social sciences." Energy Research E Social Science 5 (2015): 1-8. https://doi.org/10.1016/j.erss.2014.12.021.

24. Sule, Isaiah Majin, and Mary Oluwatobi Odekunle. Landscapes of West Africa: A Window on a Changing World. CILLS: Landscapes of West Africa: A Window on a Changing World. US Geological Survey, EROS 47914, 252nd Street, Garretson, SD 57030, United States, 2016. http://repository.futminna.edu.ng:8080/jspui/handle/123456789/9123.

25. Shackleton, Sheona, and Davison Gumbo. "Contribution of non-wood forest products to livelihoods and poverty alleviation." In The Dry Forests and Woodlands of Africa, pp. 73-101. Routledge, 2010. DOI: https://doi.org/10.4324/9781849776547.

26. Malimbwi, Rogers, Emmanuel Chidumayo, Eliakim Zahabu, Stephano Kingazi, Salome Misana, Emmanuel Luoga, and Jean Nduwamungu. "Woodfuel." In The dry forests and woodlands of Africa, pp. 162-184. Routledge, 2010. https://doi.org/10.3390/su132011316.

27. Chidumayo, Emmanuel N., and Davison J. Gumbo, eds. The dry forests and woodlands of Africa: managing for products and services. Earthscan, 2010. https://books.google.com.ng/books.

28. Muir, Giulia. "The role of non-wood forest products in diets and livelihoods: quantifying the contributions." (2021). http://paduaresearch.cab.unipd.it/13260/.

29. Bourdeaux, Quentin, B. Buyck, François Malaisse, J. Matera, Michel Marlier, Bernard Wathelet, and Georges Lognay. "Wild edible mushrooms from a Zambezian woodland area (Copperbelt Province, Zambia)." Geo-Eco-Trop 27, no. 1/2 (2003): 33-44. https://www.cabdirect.org/cabdirect/welcome/?target=\%2fcabdirect\%2fabstract $\% 2$ f20053132585.

30. Ingram, Verina, and Amos Tume Nsawir. "Pygeum: Money growing on trees in the Cameroon Highlands?." The Value of Biodiversity (2007). https://www.iucn.org/sites/dev/files/import/downloads/endamana_et_al_2007.pdf\#page=36.

31. Jekayinfa, Simeon Olatayo, Joseph Ifeolu Orisaleye, and Ralf Pecenka. "An assessment of potential resources for biomass energy in Nigeria." Resources 9, no. 8 (2020): 92. https://doi.org/10.3390/resources9080092.

32. Aigbodion, A. I., I. O. Bakare, E. A. Fagbemi, E. O. Abolagba, B. Omonigho, P. O. Ayeke, M. Bausa, and E. Musa. "Viability of biogas production from manure/biomass in Nigeria using fixed dome digester." Univers. J. Agric. Res 6 (2018): 1-8. DOI: 10.13189/ujar.2018.060101.

33. Ajewole, O. I. Promotion of intra-African trade in timber and timber products. 2009. http://ir.library.ui.edu.ng/bitstream/123456789/3433/1/\%2842\%29ui_rep_ajewole_promotion_2009.pdf.

34. Owusu, F. W., L. Damnyag, E. Marfo, and J. A. Oppong. "The Demand and Supply Patterns of Timber at the Domestic Market in Ghana." Journal of Energy and Natural Resource Management $\quad$ (JENRM) $1, \quad$ no. 2 (2018). DOI: https://doi.org/10.26796/jenrm.v1i2.137.

35. Sambe, L. N., T. N. Tee, and A. E. Okwoche. "Timber Trade Species Analysis in Benue State, Nigeria." Journal of Agriculture and Ecology Research International (2018): 1-9. https://journaljaeri.com/index.php/JAERI/article/view/3683.

36. Popoola, L., Saka, J., \& Amusa, T. O.. Prospects for public-private partnership in the Nigerian forestry sector. African Journal of Rural Development, 4(1), 2020, 125-140. https://www.researchgate.net/profile/Labode-Popoola/publication. _forestry_sector/links/60cce0b4458515dc1791af40/Prospects-for-public-private-partnership-in-Nigerian-forestry-sector.pdf

37. Shaffer, Kimberly. "US Geological Survey (USGS) Water-Use Data and Research (WUDR) program overview and status as of October 22, 2020." (2020). https://pubs.er.usgs.gov/publication/70224320.

38. Almond, R. E. A., Monique Grooten, and T. Peterson. Living Planet Report 2020-Bending the curve of biodiversity loss. World Wildlife Fund, 2020. http://pure.iiasa.ac.at/id/eprint/16870/1/ENGLISH-FULL.pdf.

39. Bellefontaine, Ronald. Management of natural forests of dry tropical zones. 2000. https://portals.iucn.org/library/node/7167.

40. Larivière, Jean, and Nelly Lhermillier. L'Atlas pour la conservation des forêts tropicales d'Afrique. Ed. Jean-Pierre de Monza, 1996.

41. Molina-Flores, Baldomero, Pablo Manzano-Baena, and Mamadou D. Coulibaly. The role of livestock in food security, poverty reduction and wealth creation in West Africa. FAO, 2020. https://doi.org/10.4060/ca8385en. 